

www.czasopisma.uni.lodz.pl/foe/

$1(346) 2020$

DOI: http://dx.doi.org/10.18778/0208-6018.346.02

\author{
Agnieszka Monika Bobrowska \\ University of Opole, Faculty of Economics, Department of Theory of Economics \\ abobrowska@uni.opole.pl
}

\title{
Local Government Expenditures on Care Services vs. Demographic Changes in Poland
}

\begin{abstract}
Local governments as the smallest units of territorial self-government in Poland are responsible for providing care services. The growing number of the elderly can influence the expenditures level connected with ensuring proper care for them, and it may constitute a growing problem for local government, especially for districts with a lower level of socio-economic development. In recent years, a quite high increase in benefits amount due to care services and specialist care services has been observed. Therefore, a question arises whether a significant dependence can be observed between the share of the elderly in the population and the degree of local governments' financial burden due to providing care services. The aim of this paper is to indicate voivodeships where local governments bear the biggest burden of providing care services and to verify whether it is connected with their demographic situation. The data which were subject to the static analysis conducted came from public sources: the report of the Ministry of Family, Labour and Social Policy of the Republic of Poland and elaborations of the Central Statistic Office. The situation of particular voivodeships has been defined in the scope of society ageing and burdening local government with care services. Only in the case of half of voivodeships it has been proven that the level (low, medium or high) of burden of the said services corresponds to the same level of the number of the elderly in their population, which can confirm that the amount of care services is connected with a demographic situation of a given voivodeship.
\end{abstract}

Keywords: municipal finance, care services, the elderly

JEL: H72, I14 


\section{Introduction}

Ageing is a problem which particularly affects highly-developed countries. Japan has the highest proportion of elderly people in the world - around $26.5 \%$ in 2016. For many years, it has been building the social care system for the elderly, and now it is one of the most comprehensive social care systems in the world. In the 1990s, the responsibility for providing care services for the elderly was transferred to local or municipal governments. In 2000, the obligatory long-term care insurance was introduced. The insurance allows the country to finance care needs of elderly people (Raikhola, Kuroki, 2010: 53). More and more countries use Japanese experience and implement some solutions into their own social policy. In the United Kingdom, the problem of ageing is not as severe as the one in Japan - people over 65 accounted for $18.4 \%$ of the total population in 2016, but financing social security costs from local budgets is becoming an increasing challenge (Kavedzija, 2018).

The increase in the number of elderly people in local communities must result in higher demand for care services provided to the elderly. In the highly-developed countries, the elderly care system is evolving towards providing services at home and moving away from placing seniors in nursing homes. An example would be the Swedish system, in which a departure from institutional 24-hour care centres in favour of providing care in the place of residence is observed. One of the arguments in favour of such a solution was a reduction in the cost of care. Activities in this area are coordinated in Sweden by municipalities (Kilian et al., 2018: 120). The issue of functioning of local government units in the context of meeting the needs of local communities is widely described in the literature. The aspects regarding the degree of autonomy of local authorities in making decisions or optimising the size of local government units are emphasised (King, 1984; Arsen, 2002; Swianiewicz, Herbst, 2003). The financial situation of a local government unit may depend on many different factors. The importance of demographic factors, such as decreasing the size of the local community or ageing of the population, is increasingly emphasised (Rusmin, Astami, Scilly, 2014).

The problem of the lack of self-reliance in satisfying everyday life needs particularly refers to people of advanced age, as statistically a person's health state deteriorates with age, which has been proven by the results of the research conducted within the PolSenior project and presented by P. Błędowski. The demand for help due to reduced self-reliance grows with age, and while $14.5 \%$ respondents needing care were registered in the group age 65-69 and 70-74, in the group age $85-89$ it was $62.5 \%$, and in the group age 90 and older as much as $80.4 \%$ (Mossakowska, Więcek, Błędowski, 2012: 454).

The results of Research of European Human Living Conditions show that almost 30\% of men of advanced age in Poland in 2017 admitted that their health was poor or even very bad. Almost $68 \%$ of persons above age 60 indicated a long-term (that is lasting at least 6 months) health problems and chronic diseases. It trans- 
lated into seriously or not very seriously limited ability to do everyday activities (lasting for at least 6 months) - it was pointed out by $46.2 \%$ of respondents of advanced age (Informacja o sytuacji..., 2018: Tables: 5.1, 5.2, 5.3).

The results of the European Health Interview Survey (EHIS) conducted in 2014 showed that illnesses and chronic complaints touched almost $90 \%$ of respondents older than 60, whereas in the age group 60-69 it referred to $85.2 \%$, and in the group of 80 years and more as much as $95.2 \%$. For older age groups, a higher percentage of persons having problems with covering a distance of $500 \mathrm{~m}$ was also noted, e.g. among persons in the 60-69 age group almost $22 \%$ had such problems, and in the group of 80 years and older almost 31\% (Informacja o sytuacji..., 2018: Table 5.7).

Every third person at the age 65 or older had some difficulties with doing everyday self-service activities such as lying down and getting out of bed, sitting down and getting up from a chair, having a bath or taking a shower, getting dressed and undressed. In the group of the oldest ( 80 years and older), self-service problems were declared by $58 \%$ of respondents. It is worrying that almost $45 \%$ of persons of advanced age having problems with basic self-service had to cope with the problems on their own, because they did not have any help from a third party and no access to supportive facilities. The problems of self-service translated into difficulties in running the household - as many as $57.3 \%$ of the elderly (and $84.8 \%$ in the age group 80 and older) indicated difficulties in this area. Almost half of persons from the oldest group were not able to do heavy house duties at all, and $22 \%$ had problem with doing even light chores. The problems in this group referred also to preparing meals (43.3\%) and doing shopping (67.1\%). As many as $28 \%$ of the persons of advanced age who reported limitations in running a household did not have any help and had to cope by themselves (Informacja o sytuacji..., 2018: Tables: 5.8, 5.9). These persons should become beneficiaries of local social welfare centres and use care services or specialist care services. However, the reluctance of the persons of advanced age to use services provided by these institutions can be observed, it is due to the fact that they are associated with supporting only pathological families (Raport $z$ diagnozy..., 2018).

The growth in the number of people of advanced age in local communities has to result in an increase in the need for care services provided in the place of living. The following research question has been asked: whether we can observe a crucial dependence between the percentage of the elderly in a given population and the degree of financial burden of local governments due to providing care services. The analysis was conducted on the basis of data generated for voivodeships in Poland. The aim of this paper is to indicate the voivodeships in which local governments are the most burdened with providing care services and to check if it is connected with the demographic situation observed there. It has been hypothesised that the higher the share of the elderly population in a given population, the greater the burden on municipalities for providing care services. 
Basic statistical analysis tools were used in the research. In order to ensure the comparability of data in voivodships, the share of the elderly $(65+)$ in the total population in a given voivodship was adopted as a variable characterising the level of advancement of the ageing process. A typical area of variation was determined for this variable and an average level of ageing was assigned to it. Areas of its low and high advancement were also identified. The same methodology was used for the variable describing the burden of municipalities resulting from expenses for providing care services. The proportion of this expenditure in total municipal expenditure was adopted as a variable. Based on data from 2017, a comparison of objects located in typical areas of variability for both variables was made.

\section{Providing care services as local government's own task}

The binding law provisions in Poland oblige local governments as the smallest units of territorial self-government to carry out many social welfare tasks. Organising and providing care services, including specialist care services, in a person's place of residence is one of these responsibilities (Ustawa z dnia 12 marca 2004 r. o pomocy społecznej, art. 17). Persons of advanced age, the lonely and the ill should have access to care services and specialist care services provided by local government if they are deprived of help of other people (including close family members, a spouse, ascendants, descendants). It has to be emphasised that services can be used not only by the persons of advanced age, but they constitute the majority of beneficiaries. It was confirmed by estimations made by the Ministry of Family, Labour and Social Policy for the purpose of Programme "Care $75+$ ", they show that about $60 \%$ of beneficiaries who were granted care services in 2016 were 75 years old and older (Program “Opieka 75+” 2018, 2018: 5). Local government activities focus on providing help to satisfy everyday life needs (e.g. shopping, cleaning up), ensuring proper hygiene and nursing, and if possible ensuring contacts with the environment. Specialist care services are adapted to specialist needs connected with a particular illness or disability and the services have to be provided by professionally trained personnel. A social assistance centre which is adequate to the place of residence establishes the scope of services and frequency of their provision. These services are chargeable, but some beneficiaries can be partially or totally exempt from payments when they meet the criteria included in the resolution of Local Government Council (Ustawa z dnia 12 marca 2004 r. o pomocy społecznej, art. 50). For local governments, exemptions from payments are connected with the necessity of higher expenditures from local budgets. 
Care services (apart from specialist care services provided for persons with psychological problems) are realised as own tasks, therefore they are financed from local governments' own means. Due to the growing percentage of persons of advanced age who are potentially at risk of losing self-reliance, in the future local governments will have to allocate higher amounts to ensure the provision of indispensable care to the elderly. Surcharges for patients' stay in nursing homes (DPS), which provide $24 \mathrm{~h}$ services, constitute a huge burden. In 2006, local governments spent for this purpose about 149 million PLN and in 2017 as much as 1.4 billion PLN so almost 10 times more (Sprawozdania MPiPS-03, 2006-2017). These expenditures constitute an increasing amount of local governments' spending on social aid. In 2006 it was $0.92 \%$ of the expenses, but in 2015 the share grew to $4.85 \%$. A further increase should be expected - even up to 7.28\% in 2020 (Bobrowska, Maciejasz-Świątkiewicz, 2016: 9-26). The degree of local governments' burden due to the surcharges for a stay at nursing homes (DPS) in particular voivodeships is different. The highest burden was noted in 2016 in the following voivodeships: Warmińsko-Mazurskie, Małopolskie, Lubuskie (a yearly cost per capita in the voivodeship at the level: 45.87 PLN, 42.84 PLN and 42.19 PLN respectively), and the smallest in Mazowieckie (20.63 PLN), Kujawsko-Pomorskie (26.43 PLN), Podkarpackie (26.66 PLN), Pomorskie (26.78 PLN), and Wielkopolskie (26.80 PLN). It can be noted that the difference between the highest and the lowest burden equals $120 \%$. The upward trend of the said spending constitutes an increasingly growing financial problem for all local governments, regardless of the level of expenditures (Bobrowska, Maciejasz-Świątkiewicz, 2018: 169-184). In the context of rising spending on surcharges related to a stay in nursing homes (DPS), financing the other forms of welfare for the elderly can also be problematic. It is worth emphasising that the $24 \mathrm{~h}$ care provided by nursing homes is very expensive and local governments should be interested in development of services provided in the place of living of the person needing help. Of course, not all persons of advanced age are independent enough not to need $24 \mathrm{~h}$ care, but certainly for many the possibility of staying in their own homes and having care services provided is more desirable than a stay in a nursing home (DPS). In 2016, an average cost of seniors' stay in nursing homes (DPS) equaled about 25,000 PLN. The comparable cost of providing care services was a bit higher than $1 / 3$ of $25,000 \mathrm{PLN}$ and it equaled about 8,600 PLN, provided that local government employed its own social workers and almost 3,900 PLN when services were outsourced (Usługi opiekuńcze..., 2018: 25). 


\section{Spatial diversity of the demographic situation in Poland}

Ageing of society is the main demographic problem. The process has been observed for many years and it applies not only to Poland but also other highly developed countries. The reasons for the problem have to be seen in a fall in the birth rate and the accompanying growth of life duration. Subsequent generations have an increasingly smaller number of births and simultaneously live longer. Depopulation is another unfavourable phenomenon diagnosed in Poland, it manifests in a general decrease of population in some regions. In the case of this phenomenon, processes of migration, which mainly refer to the young, also have a great impact. Settling down and starting a family in a foreign country, they are not able to directly take care of their ageing parents. In 2017, a drop in population number was noted in comparison to 2006 in the following voivodeships: Lubelskie (2.1\%), Łódzkie (3.5\%), Opolskie (5\%), Podlaskie (1\%), Śląskie (2.6\%), and Świętokrzyskie (2.5\%) (Rocznik Demograficzny 2018, 2018: 83). Maintaining the downward trend can have a negative influence on the socio-economic development of the mentioned regions, and for local governments this may mean rising expenditures on satisfying care needs of elderly inhabitants. In the analysed period (2006-2017), in all voivodeships, the percentage of people age 65 and older in total population increased. In 2006, it was at the level from $11.67 \%$ (in the Warmińsko-Mazurskie Voivodeship) to $14.93 \%$ (in the Łódzkie Voivodeship), at the same time the average value was $13.42 \%$. Whereas at the end of 2017 , the lowest value (15.29\%) still referred to the Warmińsko-Mazurskie Voivodeship, and the highest value was again noted for the Łódzkie Voivodeship - 18.9\%. The average number for Poland equaled $16.92 \%$, so it rose in comparison to 2006 by about 3.5 percent point (see Table 1). It is worth emphasising that we deal with increasingly smaller diversity among voivodeships as far as the analysed feature is concerned. It is confirmed by values of the coefficient of variation obtained in particular years. In the whole period, its value was lower than $10 \%$, which proves the lack of diversity. Moreover, a decreasing trend shown by the coefficient can be observed. In 2006 , its value equaled $8.44 \%$, whereas at the end of 2017 it reached only 5.91\%. Despite the small diversification of the voivodeships as far as the percentage of the elderly in population is concerned, (for data from 2017) the attempt was made to define the degree of ageing process advancement. Three classes of voivodeships were distinguished - of respectively low, medium and high participation of persons of advanced age in the total number of inhabitants. The difference between the minimum value in 2017 and the maximum value was divided into three brackets:

1) $\left[\min x_{1}\right.$, average - a standard deviation], that is [15.29\%, 15.92\%], 
2) [average - a standard deviation, average + a standard deviation], that is $[15.92 \%$, $17.92 \%]$,

3) [average + a standard deviation, $\left.\max x_{1}\right]$, that is $[17.92 \%, 18.90 \%]$.

Four voivodeships were qualified to class I characterised by a low share of the elderly. These were: the Podkarpackie Voivodeship, the Pomorskie Voivodeship, the Warmińsko-Mazurskie Voivodeship, and the Wielkopolskie Voivodeship. Whereas the following three voivodeships: the Łódzkie Voivodeship, the Śląskie Voivodeship, and the Świętokrzyskie Voivodeship belonged to class III with a high number of elderly persons. The remaining voivodeships were located in class II, and this range is a typical area of variation for the variable describing the level of advancement of the ageing process. Nine voivodships can be found in this range (which is about $56 \%$ of the total number of observations). It can, therefore, be concluded that the distribution of the variable is similar to a normal distribution.

Data referring to the amount paid by local governments in the years 20062017 for care services benefits and specialist care services do not show a growing trend in the whole period (in contrast to spending on surcharges related to inhabitants' stay in nursing homes). From 2006 to 2010, the amount was systematically growing reaching the level of almost 379 million PLN (see Table 2). In the following two years, a decrease in financial expenditures of local governments on care services was noted, but from 2013 till the end of the analysed period the benefits amount was systematically increasing year by year by a greater degree - in 2016 by about $11 \%$ and in 2017 by almost $25 \%$, reaching the so far unprecedented level of over 562 million PLN. The dynamics of changes of benefits amount has to be compared with the dynamics of the population of those who were granted the benefit. In 2006, the number of beneficiaries grew more than the benefits amount, which can prove that a smaller share (in comparison to 2005) of persons using care services was exempted from payment or that the number of service hours provided was smaller. Whereas, in 2011 there appeared a greater decrease of beneficiaries compared to the decrease of the benefits amount, which could be the result of the growth in the number of service hours provided or a decrease in the population of persons entitled to a partial exemption from payments. In the following year, the drop in the population of those who were granted the benefit was smaller than the decrease of benefits amount, which probably could mean that the group of beneficiaries lacked persons exempted from payments. Since 2013 the number of beneficiaries of care services has been systematically rising, however, in the last two years the growth has remained at a high level - about $6.5 \%$ a year. In 2017, care services were provided for over 105,000 persons. The question has to be asked whether it is a beginning of a stable increasing trend. Of course, due to the progressing process of population ageing, one can suppose that the number of those who need care will definitely grow. 


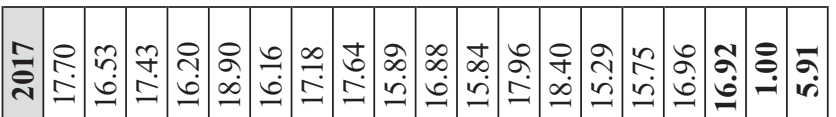

家

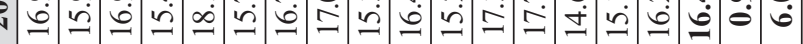

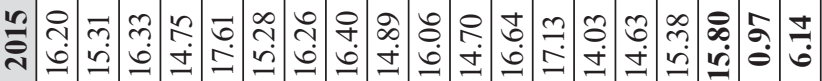

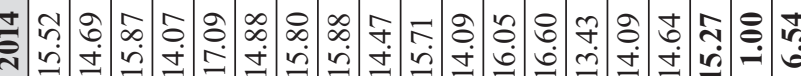

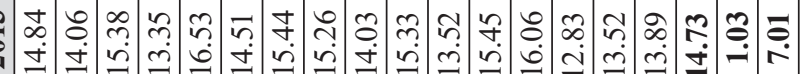

ㄱำ

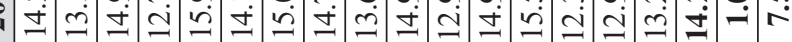

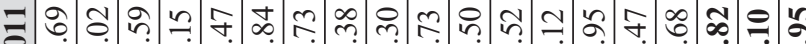

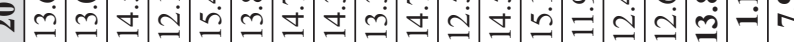

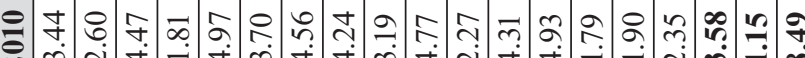

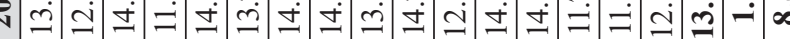

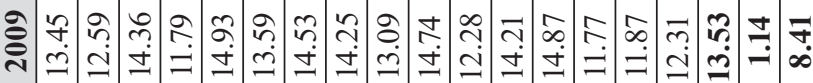

๑



ริ กุก กิ

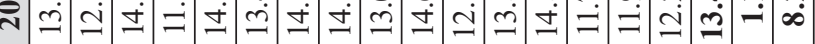

ஜำ

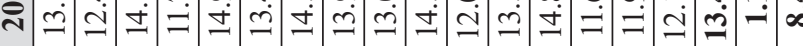

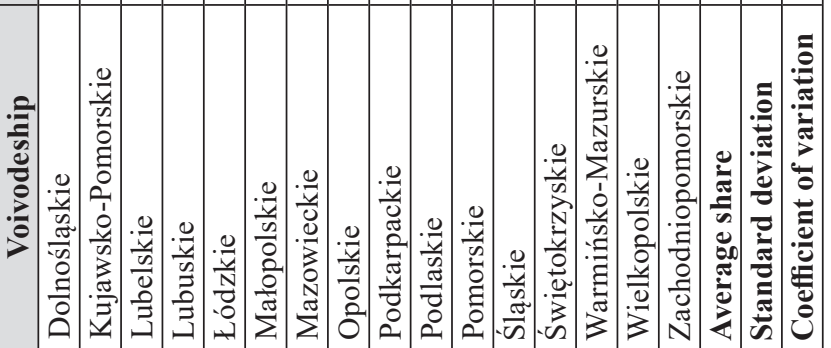


Table 2. The amounts of benefits paid by local governments for care services and specialist care services and the number of beneficiaries in Poland in the years 2006-2017

\begin{tabular}{|c|c|c|c|c|}
\hline Year & $\begin{array}{c}\text { Benefits amount } \\
\text { (PLN) }\end{array}$ & $\begin{array}{c}\text { Benefits } \\
\text { amount } \\
\text { growth (\%) }\end{array}$ & $\begin{array}{c}\text { Number of persons } \\
\text { granted the benefit }\end{array}$ & $\begin{array}{c}\text { Population growth } \\
\text { of persons granted the } \\
\text { benefit (\%) }\end{array}$ \\
\hline 2006 & 281425076 & 5.7 & 88525 & 8.0 \\
\hline 2007 & 303134286 & 7.7 & 90016 & 1.7 \\
\hline 2008 & 342389099 & 12.9 & 92470 & 2.7 \\
\hline 2009 & 366026176 & 6.9 & 91311 & -1.3 \\
\hline 2010 & 378817389 & 3.5 & 89298 & -2.2 \\
\hline 2011 & 371949041 & -1.8 & 87212 & -2.3 \\
\hline 2012 & 360639831 & -3.0 & 85545 & 1.7 \\
\hline 2013 & 370800615 & 2.8 & 86967 & 2.2 \\
\hline 2014 & 385591587 & 4.0 & 88880 & 4.9 \\
\hline 2015 & 407071590 & 5.6 & 93272 & 6.5 \\
\hline 2016 & 451479699 & 10.9 & 99368 & 6.4 \\
\hline 2017 & 562797149 & 24.7 & 105745 & \\
\hline
\end{tabular}

Source: own elaboration based on Sprawozdania MPiPS-03 for years 2005-2017

In the analysis of local governments' burden due to providing social care services, the percentage of the expenditures for this purpose in total local government expenses needs to be pointed out. In the years 2006-2017, the amount paid by local governments for the said services constituted from $0.25 \%$ (in 2012 and 2014) to $0.3 \%$ (in the years 2006-2008 and in 2017) of local governments' total expenditures (see Figure 1). Therefore, it can be assumed that so far providing care services was not too big a financial burden for local governments. It is worth noting that since 2014 the share has been gradually growing and that a further increase can be expected due to the rising number of persons of advanced age in local communities. Of course, the situation in particular districts may vary significantly. The growing amount of provided services can be a huge problem for less developed local governments.

Data aggregated at the voivodship level from the MRPiPS-03 reports prepared by local social assistance organisational units were used in this analysis. The burden on municipalities for providing care services was determined on the basis of the amount of benefits paid in 2017 by local social assistance organisational units from a given voivodeship. Comparability between the voivodships was ensured by calculating the share of these expenses in total expenses of municipalities.

The share of benefits amounts due to care services and specialist care services in local governments' total expenditures in particular voivodeships in Poland in 2017 was quite diverse. It is evidenced by the value of the coefficient of variation at the level $33.6 \%$. The smallest share $(0.18 \%)$ referred to the Śląskie Voivodeship and the highest $(0.6 \%)$ to the Świętokrzyskie Voivodeship (see Table 3). The difference between the minimum value in 2017 and the maximum value was divided into three brackets, whereas interval II was a typical area of variation: 
1) $\left[\min x_{1}\right.$, average - standard deviation], that is $[0.18 \%, 0.22 \%]$,

2) [average - standard deviation, average + standard deviation], that is $[0.22 \%$, $0.43 \%]$,

3) average + standard deviation, $\left.\max x_{1}\right]$, that is $[0.43 \%, 0.6 \%]$.

share in $\%$

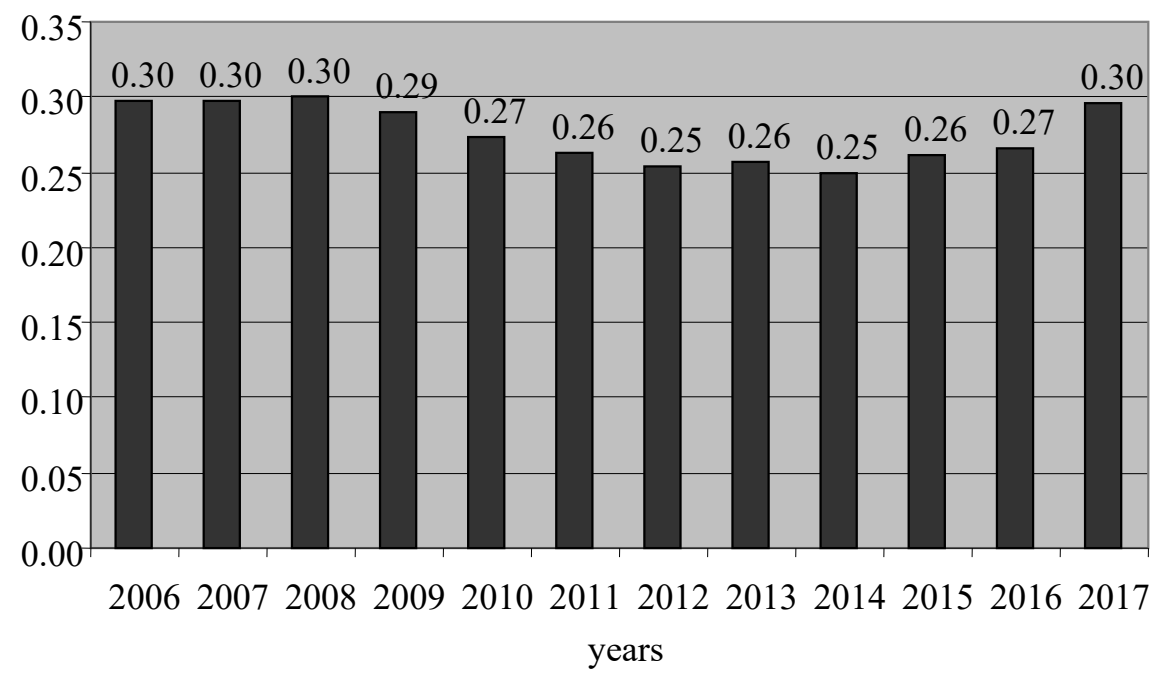

Figure 1. The share of benefits amount due to care services and specialist care services in local governments' total expenditures in Poland in the years 2006-2017

Source: own elaboration based on data from Table 2 and data from Bank Danych Lokalnych

Three classes of voivodeships were distinguished - of low, medium and high share of benefits in local governments' total expenditures. Three voivodeships were qualified as class I with a low share of expenditure. Apart from the Śląskie Voivodeship, also the Podlaskie and Mazowieckie Voivodeships fell into that category. Two voivodeships were characterised by a high share of expenditure: Świętokrzyskie and Warmińsko-Mazurskie. The other voivodeships belong to class II, defined as the typical area of variation. It contained $2 / 3$ of the analysed objects, so the distribution of the variable describing the expenditure can be considered as normal.

Table 3. The amounts of benefits paid by local governments for care services and specialist care services and the number of beneficiaries in Poland in 2017

\begin{tabular}{|l|c|c|c|}
\hline \multicolumn{1}{|c|}{ Voivodeship } & $\begin{array}{c}\text { Benefits amount } \\
\text { (PLN) }\end{array}$ & $\begin{array}{c}\text { Local governments' } \\
\text { expenditures (PLN) }\end{array}$ & $\begin{array}{c}\text { Share of benefits amount } \\
\text { in local governments' } \\
\text { expenditures (\%) }\end{array}$ \\
\hline Dolnośląskie & 53026558 & 14472676148 & 0.37 \\
\hline Kujawsko-Pomorskie & 35885065 & 9962213368 & 0.36 \\
\hline Lubelskie & 28996076 & 9520431144 & 0.30 \\
\hline
\end{tabular}




\begin{tabular}{|l|c|c|c|}
\hline \multicolumn{1}{|c|}{ Voivodeship } & $\begin{array}{c}\text { Benefits amount } \\
\text { (PLN) }\end{array}$ & $\begin{array}{c}\text { Local governments' } \\
\text { expenditures (PLN) }\end{array}$ & $\begin{array}{c}\text { Share of benefits amount } \\
\text { in local governments' } \\
\text { expenditures (\%) }\end{array}$ \\
\hline Lubuskie & 13256574 & 4692053149 & 0.28 \\
\hline Łódzkie & 29669310 & 11815173386 & 0.25 \\
\hline Małopolskie & 36775944 & 16312487936 & 0.23 \\
\hline Mazowieckie & 67807771 & 32623592741 & 0.21 \\
\hline Opolskie & 12666001 & 4149150665 & 0.31 \\
\hline Podkarpackie & 32302127 & 9624250018 & 0.34 \\
\hline Podlaskie & 11017543 & 5775169287 & 0.19 \\
\hline Pomorskie & 36017462 & 12386859332 & 0.29 \\
\hline Śląskie & 39343694 & 21795116537 & 0.18 \\
\hline Świętokrzyskie & 32797182 & 5426981388 & 0.60 \\
\hline Warmińsko-Mazurskie & 32451143 & 6733933414 & 0.48 \\
\hline Wielkopolskie & 66098334 & 16955136221 & 0.39 \\
\hline Zachodniopomorskie & 34686365 & 8243274598 & 0.42 \\
\hline
\end{tabular}

\section{Financial burden of local governments due to providing care services vs. the demographic situation in voivodeships in Poland in 2017}

Calculating the correlation coefficient was the starting point to conducting the analysis of dependence between the financial burden of local governments due to providing care services and their demographic situation. It was assumed that the more persons of advanced age in a given community the higher the financial burden of local governments due to paid benefits. While calculating the correlation coefficient for particular voivodeships, the percentage of the elderly and the share of benefits amount for the provision of care services and specialist care services in local governments' expenditures were taken into account. It has turned out that the coefficient received at the level $(-0.06)$ does not give any right to claim that there are any dependencies between the two variables. It could mean that the level of expenditures on care services in a given local government is not determined by the number of persons of advanced age.

The voivodeships classification presented above according to the low, medium and high level of percentage of elderly persons and the level of financial burden of local governments due to providing care services were compared in order to define what the situation in particular voivodeships was in 2017 (see Table 4). The Świętokrzyskie Voivodeship was characterised by a high financial burden, 
as it was the only one that also had a high share of persons of advanced age. In seven voivodeships, the medium share of persons of advanced age coincided with a medium share of benefits amount in local governments' expenditures. It can be assumed that in eight voivodeships out of 16 the level of financial burden was convergent with the percentage of the elderly. The biggest level difference appeared in the Śląskie and Warmińsko-Mazurskie Voivodeships. A high percentage of persons age $65+$ and a low burden of care services in the Śląskie Voivodeship could be a result of a better financial situation of the elderly due to higher retirement pensions of miners, and therefore a lower number of beneficiaries entitled to free care services. Proving the above-presented statement would require a detailed data analysis of not publicly available data In the Warmińsko-Mazurskie Voivodeship an opposite situation was recorded (respectively: the low percentage of the elderly and a high burden of care services). It could be caused by a worse financial situation of persons who were granted care services and the necessity of partial or total exemption from payments for the provided services. The Łódzkie Voivodeship, characterised by a high share of $65+$ persons in its population, was qualified to class II as far as the share of benefits amount in local governments' expenditures is concerned. In three voivodeships: Podkarpackie, Pomorskie and Wielkopolskie, the low level of share of the elderly was accompanied by a medium level of financial burden. The opposite situation was observed in the Mazowieckie and Podlaskie Voivodeships, which due to a low percentage of persons of advanced age were classified as class II, and taking into account the benefits amount due to care services to class I.

Confirming the hypothesis adopted in the article turned out to be impossible. In the case of half of voivodeships, a direct dependence between the demographic situation and the benefits amount paid by local governments due to care services and specialist care services cannot be confirmed. It is worth emphasising that these services were not provided at all by some local governments, which could signify the lack of demand or the lack of knowledge about possible support provided for the needy people. The number of local governments which did not provide care services as their own tasks gradually decreased from 820 in 2013 to 785 in 2015 (Majer, 2017: 109). The Ministry of Family, Labour and Social Policy preparing the Programme "Care 75+" in 2017 indicated that the lack of care services referred to the territory of about 430 local governments (Program "Opieka 75+" 2018, 2018: 6). The situation in this area will be significantly improved thanks to the implementation of the said programme.

As far as carrying out by local governments their own tasks connected with providing care for the elderly is concerned, the most worrying situation was observed in the Warmińsko-Mazurskie Voivodeship, where the lowest percentage of persons of advanced age was noted in population (15.29\%). What is surprising, it was simultaneously characterised by a high financial burden due to provid- 
ing care services as well as a high level of surcharges for the stay of inhabitants in nursing homes. The reason for the situation could be the low income of beneficiaries of care services and nursing home inhabitants, which has a direct influence on higher local government subsidies. Whereas, in comparison to other voivodeships, in the Mazowieckie Voivodeship, the situation was the best - a low level of both types of burden, that is care services and subsidies for the stay in nursing homes.

Table 4. The share level of benefits amounts for care services and specialist care services in total expenditures of local governments and the percentage of $65+$ persons in total population in voivodeship in Poland in 2017

\begin{tabular}{|c|c|c|}
\hline Voivodeship & $\begin{array}{l}\text { Percentage of persons age } 65+ \\
\text { in total population }\end{array}$ & $\begin{array}{c}\text { Share of benefits amount } \\
\text { in total expenditures of local } \\
\text { governments }\end{array}$ \\
\hline Dolnośląskie & medium & medium \\
\hline Kujawsko-Pomorskie & medium & medium \\
\hline Lubelskie & medium & medium \\
\hline Lubuskie & medium & medium \\
\hline Łódzkie & high & medium \\
\hline Małopolskie & medium & medium \\
\hline Mazowieckie & medium & low \\
\hline Opolskie & medium & medium \\
\hline Podkarpackie & low & medium \\
\hline Podlaskie & medium & low \\
\hline Pomorskie & low & medium \\
\hline Śląskie & high & low \\
\hline Świętokrzyskie & high & high \\
\hline Warmińsko-Mazurskie & low & high \\
\hline Wielkopolskie & low & medium \\
\hline Zachodniopomorskie & medium & medium \\
\hline
\end{tabular}

Source: own elaboration based on data from Table 1 and Table 3

\section{Conclusions}

The problem of burdening municipalities providing care services for the elderly taken up in the article will be the subject of further, more detailed research conducted by the author. It is necessary to consider what other factors, apart from the demographic ones, affect the level of financial burdens borne by municipalities providing care services. Data disaggregation is planned in order to enable the analysis at the municipality level, not just the voivodship level. 
In the context of ageing of local communities, the problem of increasing expenditure on helping the elderly is a huge challenge for local government, in particular for rural and rural-urban municipalities. In their case, the marginal cost of providing another service may be high. This problem was already described in the 1980 s by D.S. King (1984). When the number of beneficiaries is relatively small (compared to urban municipalities), there is often no effect of scale and it has a negative influence on the level of public service costs. The existence of such problems is indicated by employees of municipal social assistance centres. For example, the director of such a centre in Międzyrzecz Podlaski has stressed that the high costs of providing care services are due to the fact that the municipality is territorially extensive and it would be necessary to employ several caregivers full-time, which is economically inefficient (Kubicka-Żach, 2018).

In the coming years, some measures aiming to increase the availability of access to care services in particular municipalities should be undertaken in Poland. Following the example of Japan and other highly-developed countries, the implementation of an obligatory long-term insurance system should be considered.

\section{References}

Arsen Ch.A. (2002), Municipal size and democracy: A critical analysis of the argument of proximity on the case of Denmark, "Scandinavian Political Studies", vol. 25, no. 4, pp. 317-333.

Bank Danych Lokalnych, https://bdl.stat.gov.pl/BDL/start (accessed: 15.12.2018).

Bobrowska A., Maciejasz-Świątkiewicz M. (2016), Wydatki gmin z tytułu dopłat do pobytu mieszkańców w zbiorowych gospodarstwach domowych a zmiany demograficzne, "Nauki o Finansach. Prace Naukowe Uniwersytetu Ekonomicznego we Wrocławiu”, vol. 28, no. 3, pp. 9-26.

Bobrowska A., Maciejasz-Świątkiewicz M. (2018), Przestrzenne zróżnicowanie wydatków gmin na dopłaty do pobytu mieszkańców w zbiorowych gospodarstwach domowych w Polsce. Stan obecny i prognoza, "Acta Universitatis Lodziensis. Folia Oeconomica", no. 2, pp. 169-184.

Informacja o sytuacji osób starszych na podstawie badań Głównego Urzędu Statystycznego (2018), GUS, Warszawa.

Kavedzija I. (2018), Japan has the world's oldest population - this is what we can learn from their social care model, "Independent", 31 May 2018, https://www.independent.co.uk/voices/japan-elderly-social-care-system-uk-nhs-health-old-people-a8377631.html (accessed: 10.11.2019).

Kilian J., Ćwirlej-Sozańska A., Wiśniowska-Szurlej A., Wilmowska-Pietruszyńska A. (2018), System dlugoterminowej opieki domowej nad osobami starszymi w Polsce $i$ wybranych krajach europejskich, "Niepełnosprawność - Zagadnienia, Problemy, Rozwiązania", no. IV/2018(29), pp. 113-131.

King D.S. (1984), Fiscal tiers: the economics of multi-level government, Allen \& Unwin, London.

Kubicka-Żach K. (2018), Ustugi opiekuńcze sq niedofinansowane, https://www.prawo.pl/samorzad/ skad-srodki-na-uslugi-opiekuncze,289479.html (accessed: 10.11.2019).

Majer R. (2017), Bezpieczeństwo osób starszych w środowisku lokalnym - wybrane aspekty, Stowarzyszenie Pracy Socjalnej Auxilio Venire, Częstochowa.

Mossakowska M., Więcek A., Błędowski P. (eds.) (2012), Aspekty medyczne, psychologiczne, socjologiczne i ekonomiczne starzenia się ludzi w Polsce, Termedia Wydawnictwa Medyczne, Poznań.

Program "Opieka 75+" 2018 (2018), Ministerstwo Rodziny, Pracy i Polityki Społecznej, Warszawa. 
Raikhola P. S., Kuroki Y. (2010), Aging and Elderly Care Practice in Japan: Main Issues, Policy and Program Perspective; What Lessons can be Learned from Japanese Experiences?, "Dhaulagiri Journal of Sociology and Anthropology", vol. 3, pp. 41-82.

Raport $z$ diagnozy potrzeb $w$ zakresie specjalistycznych ustug opiekuńczych w gminie Bukowno (2018), Miejski Ośrodek Pomocy Społecznej w Bukownie, http://www.bukowno.naszops. pl/n,raport-z-diagnozy-potrzeb-z-zakresie-specjalistycznych-uslug-opiekunczych (accessed: 15.12.2018).

Rocznik Demograficzny 2018, http://stat.gov.pl/obszary-tematyczne/roczniki-statystyczne/roczniki-statystyczne/rocznik-demograficzny-2018,3,12.html (accessed: 15.12.2018).

Rocznik statystyczny województw (2007-2017), GUS, Warszawa.

Rusmin R., Astami E.W., Scilly G. (2014), Local government units in Indonesia: demographic attributes and differences in financial condition, "Australasian Accounting, Business and Finance Journal", vol. 8(2), pp. 86-109, http://doi.org/10.14453/aabfj.v8i2.7

Sprawozdania MPiPS-03 (2006-2017), Ministerstwo Rodziny, Pracy i Polityki Społecznej, http:// www.mpips.gov.pl/pomoc-spoleczna/raporty-i-statystyki/statystyki-pomocy-spolecznej (accessed: 15.12.2018).

Swianiewicz P., Herbst M. (2003), Korzyści i niekorzyści skali w działaniach samorzadu terytorialnego, "Samorząd Terytorialny", no. 3, pp. 44-57.

Usługi opiekuńcze świadczone osobom starszym w miejscu zamieszkania (2018), Najwyższa Izba Kontroli, Warszawa.

Ustawa z dnia 12 marca 2004 r. o pomocy społecznej (Dz.U. 2004, poz. 593 ze zm.).

\section{Wydatki gmin na usługi opiekuńcze a zmiany demograficzne w Polsce}

Streszczenie: Gminy jako najmniejsze jednostki samorządu terytorialnego w Polsce są odpowiedzialne za działania z zakresu pomocy społecznej. Rosnąca liczba osób starszych może wpływać na poziom wydatków związanych z zapewnieniem im opieki i stanowić coraz większy problem dla samorządu lokalnego, zwłaszcza dla gmin o niższym poziomie rozwoju społeczno-ekonomicznego. W ostatnich latach zaobserwowano stosunkowo wysoki wzrost kwoty świadczeń z tytułu usług opiekuńczych i specjalistycznych usług opiekuńczych. Rodzi się zatem pytanie: „Czy można zaobserwować istotną zależność między udziałem osób starszych w populacji a stopniem obciążenia finansowego gmin z tytułu świadczenia usług opiekuńczych?". Celem artykułu jest wskazanie tych województw w których gminy są najbardziej obciążone świadczeniem usług opiekuńczych i sprawdzenie, czy ma to związek z obserwowaną w nich sytuacją demograficzną. Dane poddane analizie statystycznej pochodziły z ogólnodostępnych źródeł: sprawozdań Ministerstwa Rodziny, Pracy i Polityki Społecznej oraz opracowań Głównego Urzędu Statystycznego. Określono aktualną sytuację poszczególnych województw w zakresie starzenia się społeczeństwa oraz obciążenia świadczeniami na usługi opiekuńcze. Tylko w przypadku połowy województw stwierdzono, że poziom (niski, średni lub wysoki) obciążenia przedmiotowymi świadczeniami odpowiada takiemu samemu poziomowi udziału osób starszych w populacji, co świadczyć może o związku kwoty świadczeń na usługi opiekuńcze z sytuacją demograficzną danego województwa.

Słowa kluczowe: finanse gmin, usługi opiekuńcze, osoby starsze

JEL: $\mathrm{H} 72,114$ 


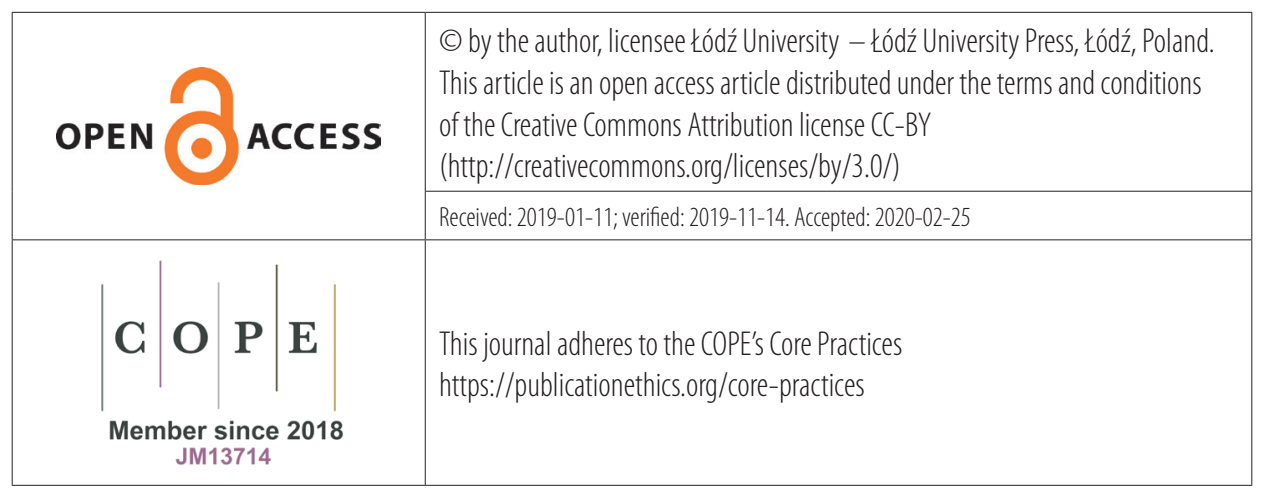

